\title{
Efforts to Improve Understanding of the Food Chain Concept Through Direct Instruction Learning Model for Elementary School Students
}

\author{
Joko Priyanto \\ SDN 2 Muruh \\ jojopriyanto@gmail.com
}

\section{Article History}

accepted 14/11/2020

approved 21/11/2020

published 26/11/2020

\begin{abstract}
The goal to be achieved in this research is to improve understanding of the concept of the food chain through the Direct Instruction learning model for grade $V$ students of SD Negeri 2 Muruh in the academic year 2020/2021. This research is a classroom action research (PTK). The research was conducted in two cycles. Each cycle consists of planning, acting, observing, and reflecting. The subjects of this study were students of class V SD Negeri 2 Muruh with 16 students. Data collection techniques using documentation, observation, and tests. The data analysis technique used is a comparative descriptive model, which is to compare the value of students' understanding of the food chain concept from the initial conditions, cycle I, to cycle II. The results showed an increase in the class average score and the number of students who completed learning in each cycle. In the initial conditions, the class average score was only 67.93 with the number of students who completed as many as 8 students or $50 \%$. The class average score in the first cycle increased to 71.68 with 10 students who completed or $62.5 \%$. Then in cycle II the class average score became 80.62 with 14 students or $87.5 \%$ of the total students who completed. The conclusion of this research is that the application of the direct instruction learning model can improve the understanding of the concept of the food chain in grade V SD Negeri 2 Muruh in the academic year 2020/2021.
\end{abstract}

Key Words: Direct instruction learning model, understanding the concept of the food chain

\begin{abstract}
Abstrak
Tujuan yang hendak dicapai dalam penelitian adalah meningkatkan pemahaman konsep rantai makanan melalui model pembelajaran Direct Instruction pada peserta didik kelas $\mathrm{V}$ Sekolah Dasar Negeri 2 Muruh tahun ajaran 2020/2021.Penelitian ini merupakan penelitian tindakan kelas (PTK). Penelitian dilaksanakan dalam dua siklus. Setiap siklus terdiri dari perencanaan, pelaksanaan tindakan, observasi, dan refleksi. Subjek penelitian ini adalah peserta didik kelas $\mathrm{V}$ SD Negeri 2 Muruh dengan jumlah peserta didik sebanyak 16 orang. Teknik pengumpulan data menggunakan dokumentasi, observasi, dan tes. Teknik analisis data yang digunakan adalah model deskriptif komparatif yaitu membandingkan nilai pemahaman konsep rantai makanan peserta didik dari kondisi awal, siklus I, hingga siklus II. Hasil penelitian menunjukkan adanya peningkatan nilai rata-rata kelas dan jumlah peserta didik yang tuntas belajar pada setiap siklus. Pada kondisi awal, nilai rata-rata kelas hanya sebesar 67,93 dengan jumlah peserta didik yang tuntas sebanyak 8 peserta didik atau sebesar $50 \%$. Nilai rata-rata kelas pada siklus I meningkat menjadi 71,68 dengan jumlah peserta didik yang tuntas sebanyak 10 peserta didik atau sebesar $62,5 \%$. Kemudian pada siklus II nilai rata-rata kelas menjadi 80,62 dengan jumlah peserta didik yang tuntas sebanyak 14 peserta didik atau sebesar $87,5 \%$. Simpulan penelitian ini adalah penerapan model pembelajaran direct instruction dapat meningkatakan pemahaman konsep rantai makanan pada peserta didik kelas V SD Negeri 2 Muruh tahun pelajaran 2020/2021.
\end{abstract}

Kata Kunci: Model pembelajaran direct instruction, Pemahaman konsep rantai makanan

Social, Humanities, and Education Studies (SHEs): Conference Series https://jurnal.uns.ac.id/shes

p-ISSN 2620-9284

e-ISSN 2620-9292 


\section{PENDAHULUAN}

Aktivitas belajar merupakan keterlibatan peserta didik dalam bentuk sikap, pikiran, dan perhatian dalam kegiatan belajar guna menunjang keberhasilan proses belajar mengajar dan memperoleh manfaat dari kegiatan tersebut. Aktivitas belajar sangat penting dalam menunjang proses belajar mengajar karena dengan aktivitias belajar maka proses belajar mengajar dapat berjalan sesuai dengan rencana pengajaran yang telah dibuat oleh guru sebelumnya. Keterlibatan peserta didik baik secara intelektual maupun emosional dalam proses belajar mengajar menentukan keberhasilan dalam pembelajaran. Apabila peserta didik terlibat aktif dalam proses belajar mengajar maka tujuan pembelajaran dapat tercapai. Diharapkan dengan terlibat aktif dalam proses belajar mengajar hasil belajar peserta didik akan meningkat seperti yang dikemukakan oleh Sudjana (2009:22) bahwa, "Hasil belajar adalah kemampuan yang dimiliki peserta didik setelah ia menerima pengalaman belajarnya". Hamalik (2009:155) juga mengemukakan bahwa, "Hasil belajar tampak sebagai terjadinya perubahan tingkah laku pada diri peserta didik, yang dapat diamati dan diukur dalam bentuk perubahan pengetahuan sikap dan ketrampilan"

Namun demikian, proses pembelajaran di kelas menghadapi beberapa kendala. Proses pembelajaran tidak selamanya berjalan lancar dan sesuai dengan yang diharapkan. Pelaksanaan proses pembelajaran terkadang tidak mencapai tujuan yang diharapkan dalam proses maupun hasilnya. Kurikulum 2013 saat ini mengubah paradigma bahwa guru memberikan pengetahuan kepada peserta didik yang pasif menjadi peserta didik yang berperan aktif dan berinisiatif dalam proses pembelajaran di kelas. Peserta didik memiliki peran yang menonjol dalam proses pembelajaran dan guru bertindak sebagai pengarah, fasilitator, dan motivator bagi peserta didik dalam proses belajar.

Berdasarkan hasil pengamatan yang dilakukan selama pandemi COVID-19 ini aktivitas pembelajaran yang dilakukan anak masih kurang karena pembelajaran hanya melalui gawai. Peserta didik hanya mendapatkan materi yang dikirim guru melalui gawai dan diberi tugas. Pembelajaran seperti ini kurang efektif. Motivasi belajar peserta didik rendah sehingga peserta didik kurang memahami materi. Hal tersebut berakibat rendahnya prestasi belajar yang didapatkan peserta didik. Dari 16 peserta didik di kelas $V$ hanya 9 anak (56,25\%) yang mendapatkan nilai di atas 70 (KKM 70).

Berdasarkan paparan di atas, maka peneliti mengambil inisiatif suatu sistem pembelajaran yang melibatkan peran peserta didik secara aktif dalam kegiatan belajar mengajar, guna meningkatkan pemahaman konsep rantai makanan. Salah satu model dan media pembelajaran yang melibatkan peran peserta didik secara aktif yang menyenangkan adalah model pembelajaran Langsung (Direct Instruction).

Model pembelajaran langsung (Direct Instruction) merupakan salah satu pendekatan mengajar yang dirancang khusus untuk menunjang proses belajar peserta didik yang berkaitan dengan pengetahuan deklaratif dan pengetahuan prosedural yang terstruktur dengan baik yang dapat diajarkan dengan pola kegiatan bertahap, selangkah demi selangkah. Suatu pembelajaran akan bermakna bagi peserta didik jika guru mengetahui tentang obyek yang akan diajarkannya sehingga dapat mengajarkan materi tersebut dengan penuh dinamika dan inovasi.

Rantai Makanan adalah peristiwa makan dan dimakan yang terjadi pada makhluk hidup. Hubungan saling ketergantungan antar makhluk hidup dapat berupa hubungan makan dan dimakan. Hubungan ini akan membentuk rantai makanan. Jaring-jaring makanan adalah sekumpulan rantai makanan dalam suatu lingkungan sehingga membentuk jaring-jaring makanan. (Sulistyanto, 2008: 64). Dalam suatu ekosistem terjadi proses makan dan di makan yang di lakukan organisme untuk memperoleh tenaga atau energi. Jadi,proses makan dan di makan dalam suatu rantai makanan dan jaring-jaring makanan dapat di katakan sebagai proses aliran energi. 
Di antara produsen, konsumen dan pengurai adalah saling ketergantungan.Tidak ada makhluk hidup yang hidup tanpa makhluk lainnya.Setiap makhluk hidup memerlukan makhluk hidup lainnya untuk saling mendukung kehidupan baik secara langsung maupun tak langsung.Hubungan saling ketergantungan antar produsen, konsumen dan pengurai. Terjadi melalui peristiwa makan dan memakan melalui peristiwa sebagai berikut: Rantai makanan merupakan perstiwa makan dan dimakan dalam suatu ekosistem dengan urutan tertentu. Tumbuhan menggunakan sinar matahari untuk menghasilkan makanan dalam bentuk gula, dan disimpan dalam dalam biji, batang, dan bagian lainnya. Tikus makan tumbuhan. Tubuh tikus mengubah sejumlah makanan menjadi energi untuk Iri, makan, dan bereproduksi. Ular makan tikus. Tikus merupakan sumber energi untuk ular agar tetap hidup. Burung Elang makan ular. Tubuh elang menggunakan energi yang tersedia dari ular untuk melangsungkan proses kehidupan.

Model pembelajaran merupakan cara yang digunakan untuk mengimplementasikan rencana yang sudah disusun dalam bentuk kegiatan nyata dan praktis untuk mencapai tujuan pembelajaran. Model pembelajaran yang nyata dan praktis tersebut adalah Model Pembelajaran Langsung (Direct Instruction). Model Pembelajaran Langsung (Direct Instruction) adalah salah satu model pembelajaran yang dikembangkan oleh Roshenshina dan Stevens di tahun 1986. Namun sebelum itu menurut Arends dalam Trianto, landasan penelitian dari Model Pembelajaran Langsung dan berbagai komponennya, berasal dari bermacam-macam bidang. Meskipun demikian, data penunjang empiriks yang paling jelas terhadap Model Pembelajaran Langsung (Direct Instruction) berasal dari penelitian tentang keefektifan guru yang dilakukan pada tahun 1970-an dan 1980-an oleh Stalling dan Koskowitz dengan hasil menunjukkan bahwa guru yang memiliki kelas yang terorganisasikan dengan baik menghasilkan rasio keterlibatan peserta didik (Time-Taks-Rations) yang lebih tinggi daripada guru yang menggunakan pendekatan yang kurang formal dan kurang terstruktur oleh guru kepada peserta didik. Penyusunan waktu yang digunakan untuk mencapai tujuan pembelajaran harus seefisien mungkin, sehingga guru dapat merancang dengan tepat waktu yang digunakan.

Model Pembelajaran Langsung (Direct Instruction) adalah salah satu pendekatan mengajar yang dirancang khusus untuk menunjang proses belajar peserta didik yang berkaitan dengan pengetahuan deklaratif dan pengetahuan prosedural yang terstruktur dengan baik yang dapat diajarkan dengan pola kegiatan bertahap, selangkah demi selangkah. Berdasarkan pengertian pembelajaran langsung yang dikemukakan (Sofan Amri \& lif Khoiru Ahmadi, 2010:39) bahwa Model Pembelajaran Langsung (Direct Instruction) merupakan salah satu model pengajaran yang dirancang khusus untuk mengembangkan belajar peserta didik tentang pengetahuan prosedural dan pengetahuan deklaratif yang terstruktur dengan baik dan dapat dipelajari selangkah demi selangkah. Yang dimaksud dengan pengetahuan deklaratif (dapat diungkapkan dengan katakata) adalah pengetahuan tentang sesuatu. sedangkan pengetahuan prosedural adalah pengetahuan tentang bagaimana melakukan sesuatu. Arends dalam Sugiarto (2008:49), mengatakan: "Model pembelajaran langsung dikembangkan secara khusus untuk meningkatkan proses pembelajaran para peserta didik terutama dalam hal memahami sesuatu (pengetahuan) dan menjelaskannya secara utuh sesuai pengetahuan procedural dan pengetahuan deklaratif yang diajarkan secara bertahap".

Penelitian peningkatan pemahaman konsep rantai makanan dengan model pendekatan direct instruction pada kelas V SD Negeri 2 Muruh Kecamatan Gantiwarno Kabupaten Klaten ini tidak terlepas atau mengacu dari penelitian sebelumnya. Pada skripsi Elistina yang berjudul Penerapan Model Pembelajaran Langsung (Direct Instruction) Berbantuan Gambar Untuk Meningkatkan Hasil Belajar Peserta didik Pada Mata Pelajaran IPA di Kelas V SDN 5 Basi Kecamatan Basidondo Tolitoli. Hasil penelitian ini menunjukkan bahwa ketuntasan belajar dengan penerapan model 
Pembelajaran Langsung (Direct Instruction) dapat meningkatkan hasil belajar peserta didik kelas V SDN 5 Basi Kecamatan Basidondo Tolitoli. Selanjutnya pada skripsi Siti Mambau Sururunni'mah yang berjudul. Penerapan model pembelajaran langsung (Direct Instruction) dengan media kartu aksara untuk meningkatkan hasil belajar Bahasa Jawa peserta didik kelas IV MI Wajib Belajar Hidayatut Thullab Kamulan Durenan Trenggalek. Hasil penelitian ini menunjukkan bahwa ketuntasan belajar dengan penerapan model Pembelajaran Langsung (Direct Instruction) dapat meningkatkan hasil belajar peserta didik kelaskelas IV MI Wajib Belajar Hidayatut Thullab Kamulan Durenan Trenggalek. Berdasarkan rumusan masalah tersebut, maka tujuan yang hendak dicapai dalam penelitian adalah meningkatkan pemahaman konsep rantai makanan melalui model pembelajaran Direct Instruction pada peserta didik kelas V Sekolah Dasar Negeri 2 Muruh.

\section{METODE}

Penelitian Tindakan Kelas (PTK) yang digunakan peneliti adalah jenis PTK kolaboratif. PTK kolaboratif yaitu kerja sama antara peneliti dengan teman sejawat, ide berasal dari peneliti dan yang melakukan tindakan adalah guru mata pelajaran IPA kelas V SDN 2 MURUH Gantiwarno Klaten di lakukan pada semester I. Unit penelitian adalah kelas V SDN 2 MURUH. Penelitian ini dilaksanakan pada semester I tahun pelajaran 2020/2021. Subjek dalam penelitian ini adalah peserta didik kelas kelas $V$ SDN 2 MURUH Gantiwarno Klaten dengan jumlah peserta didik 16 anak. Teknik pengumpulan data yang dipakai dalam penelitian tindakan ini adalah teknik tes dan non tes yang terdiri dari: Tes berbentuk pilihan ganda, digunakan untuk mengukur kemampuan peserta didik melalui model pembelajaran direct instruction. Non tes dalam penelitian ini berupa pengamatan implementasi RPP, pengamatan aktivitas peserta didik dan penilaian proses. Pengamatan implementasi RPP digunakan untuk mendapat data tentang pengajaran guru didalam kelas serta pengamatan keaktifan peserta didik, sehingga bisa dilihat di dalam pelaksanaan pembelajaran benar-benar sesuai dengan kondisi dan proses yang diharapkan. Pengamatan melalui diskusi dan presentasi dilakukan terhadap proses pembelajaran melalui model pembelajaran direct instruction. Dokumentasi digunakan untuk mendapatkan data tentang identitas dari peserta didik. Dalam hal ini data yang diperoleh adalah daftar peserta didik menonjol baik dari segi positif maupun negatifnya. Teknik analasis data yang digunakan Teknik analis data yang peneliti gunakan dalam penelitian untuk mengetahui tingkat keberhasilan belajar peserta didik kelas V SDN 2 Muruh melalui model pembelajaran direct instruction yaitu teknik deskriptif komparatif yakni teknik statistik dengan membandingkan skor antar siklus, persentase, mean, skor minimal, maksimal.

\section{HASIL DAN PEMBAHASAN}

Penelitian yang telah dilakukan akhirnya diperoleh data-data yang dapat diuraikan sebagai berikut: Perencanaan Penelitian. Kegiatan yang dilakukan dalam tahapan ini adalah menyiapkan segala sesuatu yang diperlukan dalam melaksanakan skenario pembelajaran siklus I yang telah direncanakan. Kegiatan yang dilakukan antara lain: Membuat Rencana Pelaksanaan Pembelajaran (RPP) dengan materi Rantai makanan. Menyiapkan lembar observasi (pengamatan) sebagai pedoman atas proses pembelajaran menggunakan video powerpoint. Menyusun soal tes untuk menilai peningkatan hasil belajar peserta didik terhadap materi yang diajarkan.

Pelaksanaan tindakan di ilakukan pada tanggal 2 Nopember 2020. Deskripsi pelaksanaan tindakan pembelajaran adalah sebagai berikut : Pertemuan Pertama. Tahap pelaksanaan tindakan merupakan tahap pelaksanaan seluruh rencana pembelajaran yang telah disusun pada tahap perencanaan. Pada tahap ini peneliti bertindak sebagai guru dan rekan sejawat bertindak sebagai observer. Alokasi waktu 
yang digunakan ialah dua jam pelajaran atau $2 \times 35$ menit. Perincian tahap pelaksanaan tindakan pada siklus I sebagai berikut: Tahap prakegiatan pembelajaran dimulai dengan guru membagikan link google meet melalui WAG, mengucap salam kemudian mengkondisikan kelas dilanjutkan dengan berdoa. Seluruh peserta didik kelas $\mathrm{V}$ hadir dan mengikuti kegiatan pembelajaran pada pertemuan ini. Apersepsi pada pertemuan ini ialah guru memberikan penjelasan makan dan dimakan antara makhluk hidup dalam kehidupan sehari-hari yang dapat menuntun peserta didik untuk masuk ke dalam materi yang akan diajarkan. Kemudian guru menyampaikan tujuan dari pembelajaran yaitu mempelajari tentang rantai makanan dan komponen rantai makanan.

Pada kegiatan inti ini, peneliti menyajikan materi sekilas tentang rantai makanan dengan bantuan audio visual. Adapun langkah pertama, seluruh peserta didik dilihatkan makhluk hidup pada ekosistem sawah. Setelah seluruh peserta didik makhluk hidup di ekosistem sawah, langkah kedua mereka ditugaskan untuk mengurutkan makhluk hidup tersebut tersebut pada lembar tugas yang telah tersedia. Langkah ketiga, peneliti kemudian memberikan penjelasan singkat dan beberapa contoh prosedur penyusunan rantai makanan dengan benar. Seluruh peserta didik memperhatikan secara seksama penjelasan yang disampaikan oleh peneliti. Peneliti juga melibatkan peserta didik dalam pemberian contoh, hal ini bertujuan agar seluruh peserta didik memperhatikan dan bersiap-siap untuk mengerjakan pertanyaan dari peneliti secara acak. Peserta didik sangat antusias dalam mengikuti pembelajaran.

Langkah selanjutnya, untuk melihat pemahaman peserta didik tentang materi yang telah disampaikan, maka peneliti memberikan tugas Ikpd berupa insertion sort Rantai Makanan melalui WAG. Sebelum dibagikan kepada masing-masing kelompok, peneliti menjelaskan aturan pengisian tersebut. Peneliti memberikan waktu \pm 10 menit untuk mengerjakan tugas tersebut. Setelah itu, perwakilan diminta untuk mempresentasikan hasil kerja mereka dan hasil kerja peserta didik dikirimkan ke peneliti melalui WA. Setelah mengerjakan lembar kerja peserta didik, langkah selanjutnya peserta didik diminta mengerjakan soal tes evaluasi. Tes evaluasi ini dalam bentuk google form. Peneliti membagikan link soal Post Test atau tes akhir siklus I melalui WAG. Soal ini terdiri atas 10 soal pilihan ganda. Sebelum mengerjakan, peneliti mengkondisikan peserta didik untuk siap mengerjakan tugas. Setelah itu peneliti membagikan link google form di WAG yang diberi waktu kurang lebih 15 menit.

Sebelum menutup pembelajaran, peneliti mengajak seluruh peserta didik untuk mereview pembelajaran dengan meresume kegiatan tersebut dengan mencatat poin poin penting, memberikan penguatan, dan menyimpulkan kegiatan pembelajaran yang telah dilaksanakan. Untuk kegiatan tindak lanjut, peneliti memilih pekerjaan rumah (PR). Tak lupa peneliti juga memberikan kesempatan kepada seluruh peserta didik untuk menyampaikan pendapatnya tentang pembelajaran yang telah diikuti. Kegiatan pun diakhiri dengan do'a dan salam penutup serta mengingatkan kembali untuk mematuhi protokol kesehatan.

Tahap observasi dilakukan bersamaan dengan pelaksanaan tindakan. Mengacu pada lembar observasi, pengamat (observer) mengamati jalannya proses pembelajaran daring menggunakan platform google meet. Setiap aspek dicatat pada lembar observasi yang tersedia ketika pertemuan berlangsung. Peneliti dibantu oleh teman sejawat yakni Sukisto Ragil Prabowo yang mengamati aktifitas peneliti saat melakukan pembelajaran daring. Untuk lembar observasi peserta didik dilakukan oleh peneliti sendiri saat melaksanakn pembelajaran daring dengan menggunakan platform google meet.

Prestasi belajar peserta didik berdasarkan hasil Post Test siklus I sudah mengalami peningkatan. Hal ini terbukti dengan meningkatnya ketuntasan belajar peserta didik dari 50\% (Pre Test) menjadi 62, 5\% (Post Test siklus I). Namun 
ketuntasan belajar tersebut sudah sesuai dengan yang diharapkan, yaitu minimal $60 \%$ dari jumlah peserta didik yang mengikuti tes.

Dari hasil refleksi tersebut, dapat disimpulkan bahwa diperlukan tindakan selanjutnya yaitu siklus II dalam pembelajaran rantai makanan. Hasil yang diperoleh dari tindakan siklus I melalui pengamatan dan penilaian hasil belajar rantai makanan kemudian dianalisis. Hal ini digunakan sebagai langkah yang dilakukan pada siklus berikutnya. Berdasarkan hasil tes evaluasi, dapat dilihat pemahaman konsep rantai makanan dengan model direct instruction mengalami peningkatan. Nilai hasil pemahaman konsep rantai makanan peserta didik kelas V SDN 2 Muruh pada siklus I terdapat pada tabel dibawah ini.

Tabel 1. Distribusi Frekuensi Hasil Pemahaman Konsep Rantai Makanan Siklus I

\begin{tabular}{cccccc}
\hline No & Interval & $\mathrm{Fi}$ & $\mathrm{Xi}$ & $\mathrm{FiXi}$ & Persentase \\
\hline 1. & $56-62$ & 6 & 59 & 354 & $30,86 \%$ \\
2. & $63-69$ & 0 & 66 & 0 & $0 \%$ \\
3. & $70-76$ & 4 & 73 & 292 & $25,46 \%$ \\
4. & $77-83$ & 3 & 80 & 240 & $20,92 \%$ \\
5. & $84-90$ & 3 & 87 & 261 & $22,66 \%$ \\
& Jumlah & 16 & 366 & 1147 & $100 \%$ \\
& Ketuntasan klasikal $=10: 16 \times 100=62,5 \%$ & \\
\hline
\end{tabular}
berikut :

Data dalam tabel diatas dapat disajikan dalam grafik pada gambar sebagai

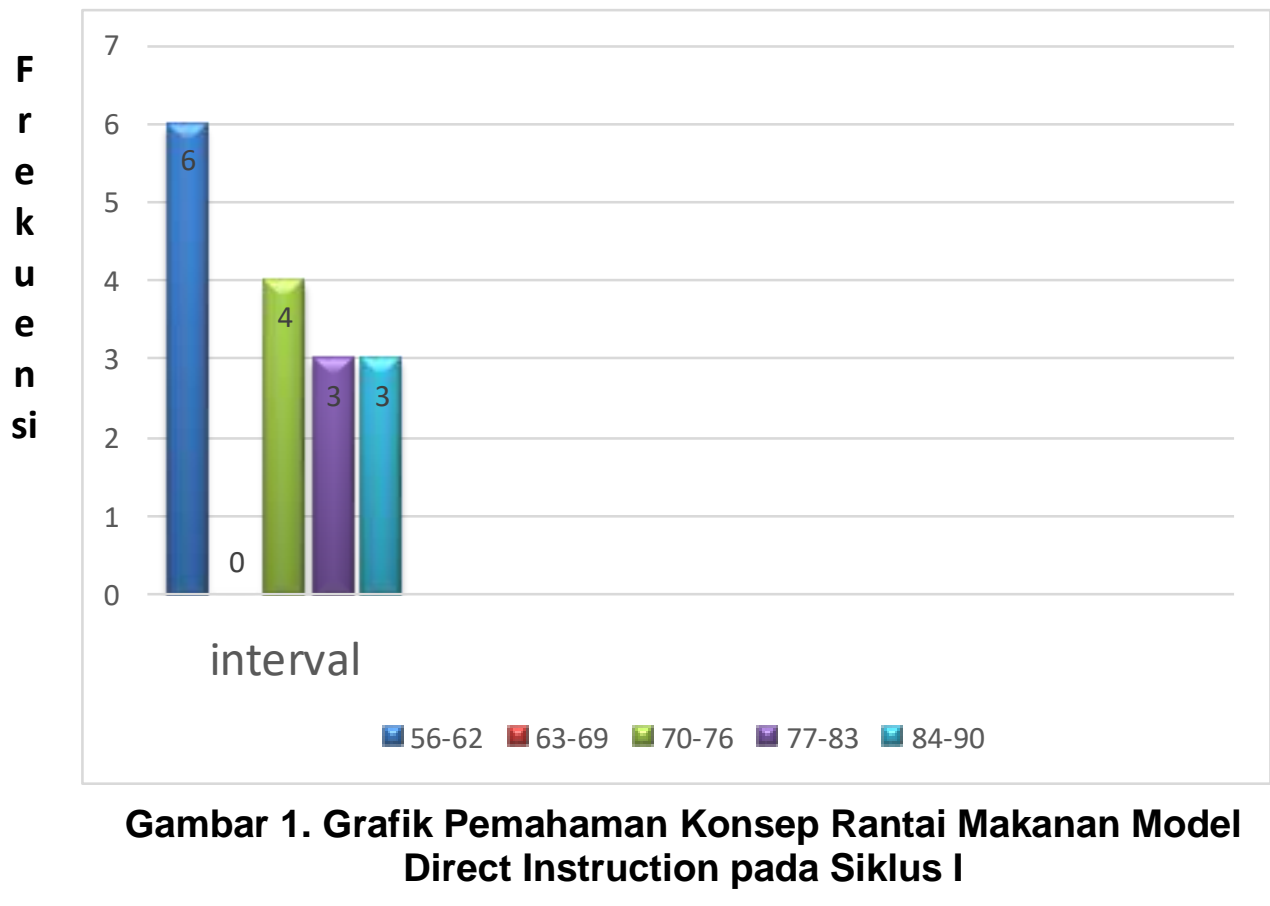


Siklus II. Penelitian yang telah dilakukan akhirnya diperoleh data-data yang dapat diuraikan sebagai berikut: Perencanaan Penelitian. Kegiatan yang dilakukan dalam tahapan ini adalah menyiapkan segala sesuatu yang diperlukan dalam melaksanakan skenario pembelajaran siklus I yang telah direncanakan. Kegiatan yang dilakukan antara lain: Membuat Rencana Pelaksanaan Pembelajaran (RPP) dengan materi rantai makanan ekosistem laut. Menyiapkan lembar observasi (pengamatan) sebagai pedoman atas model pembelajaran direct instruction. Menyusun soal tes untuk menilai peningkatan hasil belajar peserta didik terhadap materi yang diajarkan.

Pelaksanaan Tindakan. Kegiatan siklus II ini dilaksanakan pada hari Senin tanggal 9 November 2020 yang terdiri atas dua jam pelajaran yaitu 2 x 35 menit. Dengan rincian kegiatan sebagai berikut: Pada kegiatan pendahuluan ini, peneliti membagikan link google meet serta mempersiapkan para peserta didik untuk tidak ramai agar siap menerima pelajaran. Kegiatan ini diawali dengan mengucapkan salam dan mengajak berdo'a peserta didik. Kemudian mengecek kehadiran peserta didik. Selanjutnya peneliti menyampaikan tujuan pembelajaran yang ingin dicapai, melakukan apresepsi, serta memotivasi peserta didik agar berpartisipasi aktif dalam pelajaran.

Pada kegiatan inti ini, peneliti menyajikan informasi tahap demi tahap tentang rantai makanan pada ekosistem laut dengan bantuan media gambar rantai makanan pada ekosistem laut. Adapun langkah selanjutnya, peneliti menjelaskan mengenai cara mengurutkan rantai makanan dan menggambar rantai makanan pada ekosisitem laut beserta keterangannya dengan benar. Lalu Peneliti melanjutkan kegiatan pembelajaran berupa diskusi menyelesaikan LKPD, lalu perwakilan kelompok untuk mempresentasikan hasilnya. Langkah selanjutnya peserta didik diminta mengerjakan soal tes evaluasi. Tes evaluasi ini dalam bentuk google form. Peneliti meminta bantuan kepada orang tua peserta didik untuk mengawasi kerja peserta didik sambil mengingatkan bahwa soal tersebut harus dikerjakan secara jujur.

Sebelum menutup pembelajaran, peneliti mengajak seluruh peserta didik untuk meluruskan kesalahpahaman, memberikan penguatan, dan menyimpulkan serta meresume kegiatan pembelajaran yang telah dilaksanakan. Untuk kegiatan tindak lanjut, peneliti memilih pekerjaan rumah (PR). Tak lupa peneliti juga memberikan kesempatan kepada seluruh peserta didik untuk menyampaikan pendapatnya tentang pembelajaran yang telah diikuti. Kegiatan diakhiri dengan berdoa dan mengingatkan kembali untuk mematuhi protokol kesehatan.

Tahap observasi dilakukan bersamaan dengan pelaksanaan tindakan. Mengacu pada lembar observasi, pengamat (observer) mengamati jalannya proses pembelajaran daring menggunakan platform google meet. Setiap aspek dicatat pada lembar observasi yang tersedia ketika pertemuan berlangsung. Peneliti dibantu oleh teman sejawat yakni Sukisto Ragil Prabowo yang mengamati aktifitas peneliti saat melakukan pembelajaran daring. Untuk lembar observasi peserta didik dilakukan oleh peneliti sendiri saat melaksanakn pembelajaran daring dengan menggunakan platform google meet.

Pada Post Test siklus II peserta didik mengalami kemajuan daripada pada saat siklus I. Prosentase ketuntasan belajar peserta didik pada siklus I yaitu 62,5\% sedangkan pada siklus II meningkat menjadi $87,5 \%$ meski sudah melampaui kriteria ketuntasan yang diharapkan, yaitu lebih dari $60 \%$ dari jumlah peserta didik yang mengikuti tes. 
SHEs: Conference Series 3 (3) (2020) 818- 826

Tabel Distribusi Frekuensi Hasil Pemahaman Konsep Rantai Makanan Siklus II

\begin{tabular}{cccccc}
\hline No & Interval & $\mathrm{Fi}$ & $\mathrm{Xi}$ & $\mathrm{FiXi}$ & Persentase \\
\hline 1. & $56-62$ & 2 & 59 & 118 & $9,22 \%$ \\
2. & $63-69$ & 0 & 66 & 0 & $0 \%$ \\
3. & $70-76$ & 2 & 73 & 146 & $11,41 \%$ \\
4. & $77-83$ & 4 & 80 & 320 & $25,00 \%$ \\
5. & $84-90$ & 8 & 87 & 696 & $54,37 \%$ \\
& Jumlah & 16 & 366 & 1280 & $100 \%$ \\
\multicolumn{5}{r}{ Ketuntasan klasikal $=14: 16 \times 100=87,5 \%$} \\
\hline
\end{tabular}
berikut :

Data dalam tabel 4 tersebut dapat disajikan dalam grafik pada gambar 6 sebagai

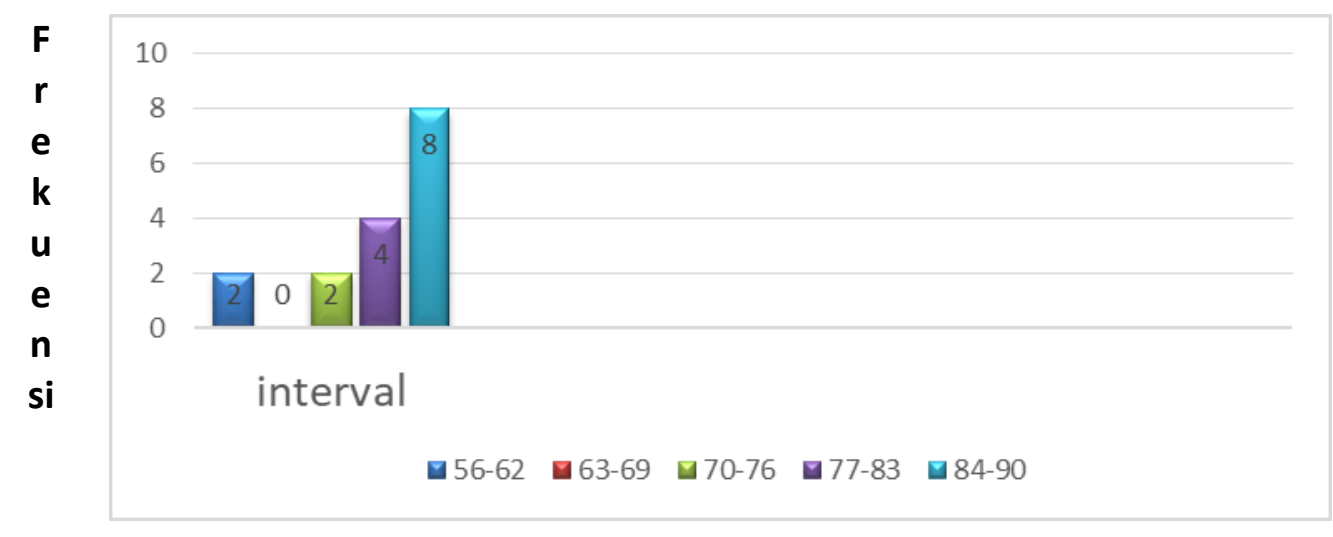

\section{Gambar 2. Grafik Pemahaman Konsep Rantai Makanan Model} Direct Instruction pada Siklus II

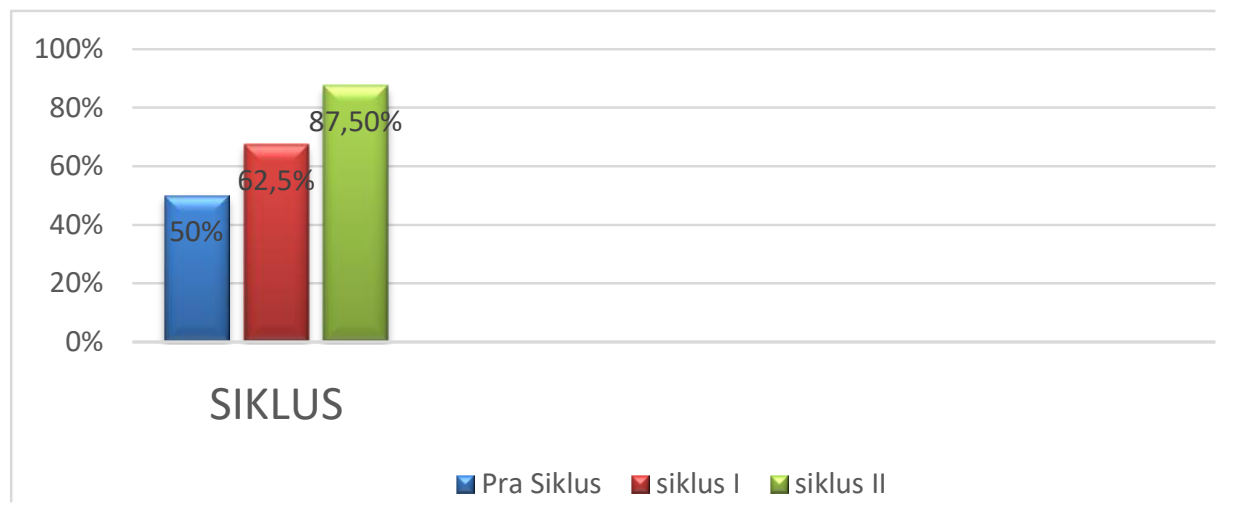

Gambar 3. Grafik perbandingan hasil belajar Pra Siklus, Siklus I dan Siklus II 


\section{SIMPULAN}

Penggunaan model pembelajaran direct instruction dapat meningkatkan hasil belajar peserta didik pada materi rantai makanan kelas V SDN 2 Muruh, Gantiwarno Klaten, hal ini dibuktikan dari hasil belajar pada siklus I yaitu peserta didik yang belum tuntas sebanyak 6 peserta didik dari 16 peserta didik atau 28,5\%, sedangkan peserta didik yang tuntas sebanyak 10 peserta didik dari 16 peserta didik atau $62,5 \%$. Pada siklus II, Pada kondisi awal sesuai dengan latar belakang penelitian, peserta didik yang belum tuntas sebanyak 6 peserta didik dari 16 peserta didik atau $38,5 \%$. Pada siklus II, peserta didik yang belum tuntas sebanyak 2 peserta didik dari 16 peserta didik atau $22,5 \%$, sedangkan peserta didik yang tuntas sebanyak 14 peserta didik dari 16 peserta didik atau $87,5 \%$. Ini artinya hasil belajar peserta didik meningkat dari siklus I ke siklus II. Hendaknya guru mengembangkan model pembelajaran direction pada materi rantai makanan di semester ini.

\section{DAFTAR PUSTAKA}

Ahmadi, H.A \& Supriyono, W. (2004). Psikologi Belajar. Jakarta: Rineka Cipta.

Amri, Sofan dan lif Khoiru Ahmadi. 2010. Proses Pembelajaran Kreatif dan Inovatif dalam Kelas. Jakarta : Prestasi Pustaka (halaman 39)

Bachman, E. (2005). Metode Belajar Berpikir Kritis dan Inovatif. Terj. Bahrul Ulum. Jakarta: Prestasi Pustakarya.

Djamarah, S.B. (2005). Guru dan Anak Didik dalam Interaksi Edukatif. Jakarta: Rineka Cipta.

Djamarah, S.B. (2008). Psikologi Belajar. Jakarta: Rineka Cipta.

Hamalik, Oemar. 2001. Proses Belajar Mengajar. Jakarta: Bumi Aksara. Hernawan, Asep Heri, dkk. 2009. Pengembangan Kurikulum dan Pembelajaran. Jakarta: Universitas Terbuka.

Samatowa, U. (2011). Pembelajaran IPA di Sekolah Dasar. Jakarta: Indeks.

Sudjana, Nana. (2009). Penilaian hasil belajar Mengajar. Bandung: PT. Remaja Rosdakarya (halaman 22).

Sukmadinata, N.S. (2010). Metode Penelitian Pendidikan. Bandung: Remaja Rosdakarya.

Sulistyanto, heri. (2008). IImu Pengetahuan Alam. Jakarta: Pusat Perbukuan Departemen Pendidikan Nasional.

Sumiati \& Asra. (2009). Metode Pembelajaran. Bandung: Wacana Prima.

Winkel.WS 2005. Bimbingan dan Konseling di Institusi Pendidikan. Yogyakarta: WaMedia Abadi.

Trianto. 2010. Model Pembelajaran Terpadu, Konsep, Strategi dan Implementasinya dalam KTSP. Jakarta: Bumi Aksara 